\title{
Efficacy of lower cut off value of serum prostate specific antigen in diagnosis of prostate cancer
}

\author{
Rashid MM, Alam AKMK, Habib AKMK, Rahman H, Hossain AKMS, Salam MA, Rahman S \\ Department of Urology, Bangabandhu Sheikh Mujib Medical University, Dhaka. \\ Email:drmamun21@yahoo.com
}

\begin{abstract}
Indications of prostate biopsy are high serum prostate specific antigen (PSA) value and or abnormal digital rectal examination (DRE) findings. Although serum PSA value of $4 \mathrm{ng} / \mathrm{ml}$ is the most commonly used threshold for recommending prostate biopsy, significant proportion of men harbor prostate cancer even when their serum PSA values are less than $4.0 \mathrm{ng} / \mathrm{ml}$. Therefore present study was designed to determine the performance status of serum PSA in lower cut-off values. This hospital based prospective study was conducted in the Department of Urology of Bangabandhu Sheikh Mujib Medical University (BSMMU) and Comfort Nursing Home Pvt. Ltd, Dhaka from July 2009 to October 2010. Two hundred six male patients aged over 50 years having lower urinary tract symptoms (LUTS) and serum PSA more than $2.5 \mathrm{ng} / \mathrm{ml}$ were prepared for prostate biopsy. Trans rectal ultrasound (TRUS) guided biopsy was done. The test statistics used to analyze the data were descriptive statistics, sensitivity, specificity, positive and negative predictive value, ROC curve. For all analytical tests, the level of significance was set at 0.05 and $\mathrm{p}<0.05$ was considered significant. In 2.5-4 serum PSA range, $28.26 \%$ (13 out of 46) of all malignancy were found, which would be missed if we take cut off value 4 . At 2.5 PSA cut-off, Sensitivity 91.3\%, Specificity 14.37\%, PPV 23.46\%, NPV 85.18\%, Efficacy $31.55 \%$. At 4 PSA cut-off value, Sensitivity $71.73 \%$, Specificity $46.25 \%$, PPV $27.73 \%$, NPV $85.05 \%$, Efficacy $51.94 \%$. So it can be concluded that, for early diagnosis of prostate cancer cut-off value of serum PSA of $2.5 \mathrm{ng} / \mathrm{ml}$ can be recommended as an indication for prostate biopsy.
\end{abstract}

\section{Introduction}

Prostate cancer is the most common cancer in men and the second leading cause of male cancer deaths in the United States. The estimated lifetime risk of disease is $17.6 \%$ for whites and $20.6 \%$ for African Americans, with a lifetime risk of death of $2.8 \%$ and $4.7 \%$ respectively ${ }^{1}$. Worldwide, prostate cancer is the fourth most common cancer in men with incidence and mortality rates that vary markedly among and within different countries ${ }^{2}$.

Unfortunately, the disease is uniformly fatal once the tumor metastasizes outside the gland. But if diagnosed early, surgery or radiotherapy provides excellent results with regard to local disease control and the prospect for long-term, disease-free survival. In the absence of effective treatment options for advanced prostate cancer, intensive efforts to detect low stage, curable cancers may help to improve prostate cancer-specific survival ${ }^{3}$.

In 1979, Wang and his colleagues at Roseville Park isolated prostate-specific antigen (PSA) from prostate tissue ${ }^{4}$. PSA appears to be the best overall serum marker for prostate cancer. The widespread use of serum Prostate Specific Antigen testing for early prostate cancer detection has increased proportion of early stage cancers detected and partially responsible for the recent decrease in prostate cancer mortality rates in the United States . A PSA cutoff of $4 \mathrm{ng} / \mathrm{ml}$ is generally used for recommending a biopsy 5 .

According to a study, cancer is detected in initial or early follow-up biopsies in more than one third of man with PSA levels greater than $4 \mathrm{ng} / \mathrm{ml}^{6}$. However, about $20 \%$ of detectable cancers occur in men with PSA values below this cutoff, and the cancer has extended beyond the prostate in one third of men with PSA levels between 4 and 10 $\mathrm{ng} / \mathrm{ml}$ and in more than half with PSA levels greater than $10 \mathrm{ng} / \mathrm{ml}^{7}$. Therefore, the use of lower PSA cutoffs may detect prostate cancer more frequently in its curable stages.

In one study surgical specimen of radical prostatectomy revealed organ confined disease in $88 \%$ for 2.6 to $4 \mathrm{ng} / \mathrm{ml}$ PSA range versus $63 \%$ for 4.0 to $10 \mathrm{ng} / \mathrm{ml}$ PSA range $(\mathrm{p}<.01)^{8}$. Screening studies have suggested that a $2.5 \mathrm{ng} / \mathrm{ml}$ PSA cutoff detects more potentially curable cancers without over detecting harmless ones ${ }^{7}$.

Prostate cancer is not uncommon in Bangladesh. Therefore, present study is designed to determine 
the sensitivity, specificity, positive and negative predictive value of PSA for diagnosis of prostate cancer in lower cut-off values.

\section{Materials and Methods}

This hospital based prospective study was conducted in the Department of Urology of Bangabandhu Sheikh Mujib Medical University (BSMMU) and Comfort Nursing Home Pvt. Ltd, Dhaka from July 2009 to October 2010 to determine the performance status of serum PSA in lower cut-off values. All male patients aged over 50 years having lower urinary tract symptoms (LUTS) attending to urology OPD were evaluated by history, clinical examination and necessary investigations to identify the potential candidates for prostate biopsy. Three hundred one patients were interviewed, 252(83.72\%) were selected according to selection criteria. Among them 206 patients having serum PSA more than $2.5 \mathrm{ng} / \mathrm{ml}$ were prepared for prostate biopsy after receiving consent. One fifty patients were taken from BSMMU and 56 patients were from Comfort Nursing Home. Patients with Serum PSA level $<2.5 \mathrm{ng} / \mathrm{ml}$, patient with bleeding disorder, anorectal pathology, active UTI or prostatitis were excluded from the study. Biopsy was done in left lateral position under the guidance of trans rectal ultrasonogram (TRUS) using biopty gun.

Data were processed and analyzed using SPSS (Statistical Package for Social Sciences) software. The statistical tests used to analyze the data were descriptive statistics, Chi-square $\left(\chi^{2}\right)$ test, sensitivity, specificity, positive and negative predictive value, ROC curve. For all analytical tests, the level of significance was set at 0.05 and $p$ $<0.05$ was considered significant.

\section{Results}

In 2.5-2.99 PSA range, $14.81 \%$ cases were malignant; in 3.0-3.49 PSA range, $17.39 \%$ cases were malignant, in 3.5-3.99 PSA range, $13.51 \%$ cases were malignant and in $>3.99$ PSA range, $27.73 \%$ cases were malignant. (Table I).

Table- I: Percentage of malignancy in various PSA range

\begin{tabular}{ccccc}
\hline PSA $(\mathrm{ng} / \mathrm{ml})$ & BPH & CaP & Total & \% of malignancy \\
\hline $2.5-2.99$ & 23 & 4 & 27 & 14.81 \\
$3.00-3.49$ & 19 & 4 & 23 & 17.39 \\
$3.5-3.99$ & 32 & 5 & 37 & 13.51 \\
$>3.99$ & 86 & 33 & 119 & 27.73 \\
\hline Total & 160 & 46 & 206 & 22.33 \\
\hline
\end{tabular}

In 2.5-3 PSA range, $8.69 \%$ (4 out of 46 ) of all malignancies were found, which would be missed if we take cut off value 3 (Table II).

Table-II: Histopathology result with PSA cut off 2.5

\begin{tabular}{cccc}
\hline PSA Range $(\mathrm{ng} / \mathrm{ml})$ & $\mathrm{CaP}$ & Total patients & $\%$ of malignancy \\
\hline $2.5-3$ & 4 & 27 & 8.69 \\
$2.5-3.5$ & 8 & 50 & 17.39 \\
$2.5-4$ & 13 & 87 & 28.26 \\
\hline
\end{tabular}

In 2.5- 3.5 serum PSA range, $17.39 \%$ (8 out of 46) of all malignancies were found, which would be missed if we take cut-off value 3.5 (Table II).

In 2.5- 4 serum PSA range, $28.26 \%$ (13 out of 46 ) of all malignancies were found, which would be missed if we take cut-off value 4 (Table II).

Sensitivity, specificity, positive and negative predictive value and efficacy at different PSA cut off was as follows-(Table III).

Table-III: Efficacy of PSA at different cut off value

\begin{tabular}{cccccc}
\hline PSA cut off & $\begin{array}{c}\text { Sensi } \\
\text { tivity }\end{array}$ & $\begin{array}{c}\text { Specifi } \\
\text { city }\end{array}$ & PPV & NPV & Efficacy \\
\hline 2.5 & 91.3 & 14.37 & 23.46 & 85.18 & 31.55 \\
3.5 & 82.6 & 26.25 & 24.35 & 84 & 38.83 \\
4 & 71.73 & 46.25 & 27.73 & 85.05 & 51.94 \\
\hline
\end{tabular}

ROC curve was made. (Fig 1) With PSA cut-off value 2.5 , AUC is $0.528(\mathrm{p}=0.557)$; with PSA cutoff value 3.5 , AUC is 0.544 ( $\mathrm{p}$ value 0.360 ); with PSA cut-off value 4, AUC is 0.590 ( $\mathrm{p}=0.063$ ) (Fig 1).

\section{ROC Curve}

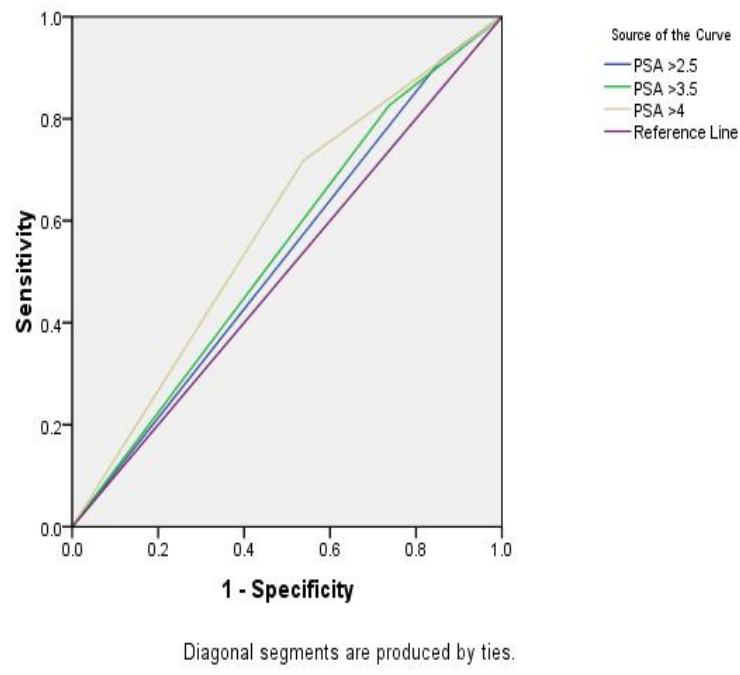

Fig 1: ROC Curve using different PSA cut off values

It was seen that $38.5 \%$ of prostate cancer diagnosed in 2.5-4 PSA range had Gleason's score 7-10, which were high grade cancer (Table IV). 
Table-IV: Comparison of Gleason's score

\begin{tabular}{ccc}
\hline Gleason's score & PSA 2.5-4 & PSA >4 \\
\hline $5-6$ & $8(61.5 \%)$ & $14(42.4 \%)$ \\
$7-10$ & $5(38.5 \%)$ & $19(57.6 \%)$ \\
\hline Total & $13(100 \%)$ & $33(100 \%)$ \\
\hline
\end{tabular}

\section{Discussion}

The use of PSA as a screening test been directed towards the early detection of prostate cancer and level of $4 \mathrm{ng} / \mathrm{ml}$ was proposed as the upper limit of normal range?. But it has been seen that a considerable proportion of prostate cancer is found at serum PSA level $<4 \mathrm{ng} / \mathrm{ml}$.

In our series, In 2.5-2.99 PSA range, $14.81 \%$ cases were malignant; 3.0-3.49 range, $17.39 \%$ cases were malignant, 3.5-3.99 range, $13.51 \%$ cases were malignant and $>3.99$ range, $27.73 \%$ cases were malignant. Early invasive investigations may result in many men undergoing unnecessary biopsy with a possible increase in the diagnosis of clinically insignificant cancers, whereas postponing prostate biopsy may result in a missed opportunity to identify early, perhaps lifesaving treatment in patients with aggressive cancers. In a large study from Washington University, biopsy in $36 \%$ of men in a screening population with PSA 2.5 to 4.0 $\mathrm{ng} / \mathrm{ml}$ revealed cancer in $22 \%^{\mathbf{1 0}}$. As is readily apparent, these findings are similar to those found in men with PSA between 4.1 and $10 \mathrm{ng} / \mathrm{ml}$.

Catalona et al (1999) reported that $83 \%$ of patients with PSA between 2.6 and $4.0 \mathrm{ng} / \mathrm{ml}$ who underwent prostatectomy had significant disease defined as greater that $0.5 \mathrm{~cm}$ tumor volume ${ }^{5}$. Whether lowering the PSA cutoff value to $2.5 \mathrm{ng} /$ $\mathrm{ml}$ will increase the disease specific survival rate remains to be determined.

In our study, in 2.5-4 serum PSA range, $28.26 \%$ of all malignancies were found, which would be missed if we take cut off value 4 . Out of 87 patients in this group, 13(14.94\%) cases were found malignant. We found that $38.5 \%$ of these tumors are poorly differentiated having $>7$ Gleason's score.

In Bangladesh in 2009, a study conducted by Rahman et al showed prostate cancer detection rate was about $15.3 \%$ in serum PSA level $<4 \mathrm{ng} / \mathrm{ml}$ group, which is consistent with our study ${ }^{11}$. Another study among screened men in India revealed 433 out of $3670(11.8 \%)$ had serum PSA concentration $>2.5 \mathrm{ng} / \mathrm{ml}$ and $58(13 \%)$ prostate cancer were diagnosed at PSA level $<4 \mathrm{ng} / \mathrm{ml}^{12}$.
The usefulness of PSA as a marker of disease activity and its correlation with survival remains controversial. Several studies have evaluated whether men with low PSA levels at diagnosis have similar or different prognosis as men with elevated PSA values at diagnosis. Some studies reported that men presenting with low PSA values had poorer outcome, some similar outcome and others reported non-significantly better outcome or significantly better outcome $\mathrm{in}^{\mathbf{1 3 , 1 4}}$.

Despite the fact that these cancers are generally localized and well differentiated tumours, a nonnegligible proportion of these patients have poorly differentiated or metastatic disease. Low PSA level per se is not an indicator of good prognosis in terms of survival ${ }^{15}$. The interpretation of PSA levels of less than $4.0 \mathrm{ng} / \mathrm{ml}$ is a challenge in decisionmaking for clinicians, as there are no widely accepted and carefully validated upper limits of normal PSA level. Another proposed predictor of $\mathrm{CaP}$ is the rate of increase in PSA levels over time (PSA velocity) ${ }^{\mathbf{1 6}}$. based on the study of increase in PSA in men who later diagnosed with $\mathrm{CaP}$, suggested that an annual increase in PSA of greater than $0.75 \mathrm{ng} / \mathrm{ml}$ per year is indicative of cancer.

In general, prostate biopsy has not been recommended unless PSA levels exceed a threshold value, with lower values recommended recently by some authors. The other study have reported that as many as $15 \%$ of men with a PSA value less than $4.0 \mathrm{ng} / \mathrm{ml}$ have prostate cancer and that $15 \%$ of these cancers are high grade ${ }^{17}$.

With an understanding that the performance characteristics of a screening test play an important role in determining its efficacy and efficiency, we report the receiver operating characteristic (ROC) curve for PSA. The result of ROC curve indicates that serum PSA value of 2.5 is considerably effective as an indication for prostate biopsy in diagnosis of prostate cancer. In this study at 2.5 PSA cut-off, Sensitivity 91.3\%, Specificity 14.37\%, PPV 23.46\%, NPV $85.18 \%$, Efficacy $31.55 \%$. This study shows that there is no single cutoff that would simultaneously yield both high sensitivity and high specificity. The standard cutoff of $4.0 \mathrm{ng} / \mathrm{mL}$ detects more higher-grade (Gleason grade 7 or more) disease. Lowering the cutoff to $2.5 \mathrm{ng} / \mathrm{ml}$ would increase sensitivity to $91.3 \%$ at the expense of decreasing the specificity to $14.37 \%$, which is consistent with another study that shows $90 \%$ sensitivity ${ }^{16}$. Patients and health care professionals must be reeducated that there is a continuum of risk and no clearly defined PSA cut point at which to recommend biopsy ${ }^{17}$. It will be the patient, in concert with his health care professional, who will ultimately have to weigh the 
sensitivity-specificity tradeoffs in combination with the uncertain natural history of the disease to determine whether further evaluation with a prostate biopsy is appropriate ${ }^{\mathbf{1 8}}$.

Conclusion: Usually, serum PSA $4 \mathrm{ng} / \mathrm{ml}$ is taken as cut off value as an indication of prostatic biopsy to diagnose prostate cancer. But about $25 \%$ of prostate cancer is missed at this PSA cut off value. For early diagnosis of prostate cancer cut off value of serum PSA of $2.5 \mathrm{ng} / \mathrm{ml}$ can be recommended as an indication for prostate biopsy. This threshold has been shown in many studies to increase the rate of cancer detection at a stage when cure is possible without materially increasing the proportion of "harmless" prostate cancer detected.

\section{References}

1. Presti JC Jr., Tanagho EA. Disorders of bladder, prostate and seminal vesicles. In: Emil A Tanagho, Jack W McAninch [editors]: Smith's General Urology, $16^{\text {th }}$ ed. New York: Lange medical book / McGraw Hill; 2004. 576-591.

2. Reiter RE, de Kernion JB. Epidemiology, etiology and prevention of prostate cancer. In: Walsh Patrick C, Retik Alan B, E Darracott Vaughan, Alan J Wein [editors]: Campbell's Urology. $8^{\text {th }}$ ed. Philadelphia: Saunders; 2002: 3003-3024.

3. PolascikTJ, Oesterling JE, Partin AW. Prostate specific antigen: A decade of discovery- What we have learned and where we are going. J Urol 2006; 162:293-306.

4. Vis AN, Kranse R, Roobol M, et al.: Serendipity in detecting disease in low prostate specific antigen ranges. BJU Int 2002; 89: 384-389.

5. Catalona WJ, Smith DS, Ornstein DK. Prostate cancer detection in men with serum PSA concentrations of 2.6 to $4.0 \mathrm{ng} / \mathrm{ml}$ and benign prostate examination. Enhancement of specificity with free PSA measurements. JAMA 2005; 277:1452-1455.

6. Shekarriz B, Upadhyay J, Bianco FJ. Impact of preoperative serum PSA level from 0 to $10 \mathrm{ng} / \mathrm{ml}$ on pathological findings and disease-free survival after radical prostatectomy. Prostate 2002; 48:136-143.

7. Babaian RJ, Johnston DA, Naccarato W. The incidence of prostate cancer in a screening population with a serum prostate specific antigen between 2.5 and 4.0 $\mathrm{ng} / \mathrm{ml}$ : relation to biopsy strategy. J Urol 2001; 165:757-760.
8. Schroder FH, van der Cruijsen-Koeter I, de Koning HJ. Prostate cancer detection at low prostate specific antigen. J Urol 2002; 163:806-812.

9. Faria EF, Carvalhal GF, Vieira RA, Silva TB, Mauad EC, Carvalho AL. Program for prostate cancer screening using a mobile unit: results from Brazil. Urology. 2010 Nov; 76(5): 1052-7.

10. Nadler RB, Loeb S, Roehl KA, Antenor JA, Eggener S, Catalona WJ. Use of $2.6 \mathrm{ng} / \mathrm{ml}$ prostate specific antigen prompt for biopsy in men older than 60 years. $\mathrm{J}$ Urol. 2005; 174: 2154-7.

11. Rahman S, Siddiq AB, Islam MS, Salam MA, Khan SA. A comparative study between TRUS guided 6 core and 12 core prostate biopsy for detection of prostate cancer. Bangladesh Journal of Urology. 2010 Jan; 13(1):14-20.

12. Deepak Dubey. The routine use of Prostate cancer antigen for early detection of prostate cancer in India: Is it justified? Indian Journal of Urology. 2009 April; 25(2): 177-184.

13. Fang J, Metter EJ, Landis P, Carter HB. PSA velocity for assessing prostate cancer risk in men with PSA levels between 2.0 and $4.0 \mathrm{ng} / \mathrm{ml}$. Urology 2002; 59: 889-93.

14. Punglia RS, D'Amico AV, Catalona WJ, Roehl KA, Kuntz KM. Effect of verification bias on screening for prostate cancer by measurement of prostate specific antigen. N Engl J Med. 2003; 349: 335-42.

15. Pelzer AE, Tewari A, Bektic J, Berger AP, Frauscher F, Bartsch G, et al. Detection rates and biologic significance of prostate cancer with PSA less than 4.0 $\mathrm{ng} / \mathrm{mL}$ : observation and clinical implications from Tyrol screening project. Urology 2005; 66: 1029-33.

16. Carter HB, Pearson JD. Prostate-specific antigen velocity and repeated measures of prostate-specific antigen. Urol Clin North Am 2005; 24: 333-338.

17. Thompson IM, Pauler DK, Goodman PJ. Prevalence of prostate cancer among men with a prostate-specific antigen level < or $=4.0 \mathrm{ng}$ per milliliter. N Engl J Med 2004; 350: 2239-2246.

18. Culp S, Porter M. The effect of obesity and lower serum prostate-specific antigen levels on prostatecancer screening results in American men. BJU Int. 2009 Nov. 104(10): 1457-61. 